\title{
SIFAT TAHAN LUNTUR DAN INTENSITAS WARNA KAIN SUTERA DENGAN PEWARNA ALAM GAMBIR (Uncaria gambir Roxb) PADA KONDISI PENCELUPAN DAN JENIS FIKSATOR YANG BERBEDA
}

\section{Properties of Fastness and Colour Strength of Silk Fabrics with Natural Dyes from Gambier (Uncaria gambir Roxb) on Different of Dyeing Condition and Kind of Fixator}

\section{Failisnur* dan Sofyan}

Balai Riset dan Standardisasi Industri Padang,

JI. Raya LIK No.23 Ulu Gadut Padang 25164

*e-mail: failisnur@gmail.com

Diterima: 4 Maret 2014, revisi akhir: 14 Mei 2014 dan disetujui untuk diterbitkan: 23 Mei 2014

\begin{abstract}
ABSTRAK
Gambir (Uncaria gambir Roxb) mengandung senyawa tanin yang dapat digunakan sebagai pewarna pada produk tekstil. Tanin merupakan senyawa komplek pada jaringan tumbuhan yang bila direaksikan dengan ion-ion logam tertentu akan membentuk warna yang spesifik. Intensitas dan arah warna kain yang dihasilkan dari dari pewarnaan yang menggunakan gambir sangat ditentukan oleh kondisi saat pencelupan dan jenis fiksator pada proses fiksasi. Tujuan penelitian adalah untuk menentukan kondisi pencelupan yang tepat dan pemilihan jenis fiksator yang diinginkan dalam menghasilkan variasi warna, nilai intensitas dan ketahanan luntur warna yang baik. Pencelupan dilakukan dalam suasana panas $\left(60-70^{\circ} \mathrm{C}\right)$ dan pada suhu kamar $\left(27-30^{\circ} \mathrm{C}\right)$, dengan pembangkit warna (fiksator) $\mathrm{Al}_{2}\left(\mathrm{SO}_{4}\right)_{3}$ (tawas), $\mathrm{CaO}$ (kapur tohor) dan $\mathrm{FeSO}_{4}$ (tunjung). Hasil penelitian didapatkan arah warna yang cukup variatif pada kain sutera mulai dari kuning, kuning keemasan, merah kecoklatan, coklat, hijau lumut sampai hijau kehitaman. Kondisi optimum diperoleh pada pencelupan panas $\left(60-70^{\circ} \mathrm{C}\right)$, jenis fiksator $\mathrm{CaO}$ yang menghasilkan intensitas dan ketuaan warna lebih tinggi (nilai K/S) sebesar 19,174 dan ketahanan luntur warna terhadap pencucian $40^{\circ} \mathrm{C}$, sinar terang hari dan penekanan panas bernilai baik sampai sangat baik (4-5).
\end{abstract}

Kata Kunci : Gambir, pewarna alam, kain sutera, intensitas warna, ketahanan luntur warna

\section{ABSTRACT}

Gambier (Uncaria gambir Roxb) contains tannin compounds that can be used as a dye for textile products. Tannins are complex compounds in plant tissues when reacted with certain metal ions will form a specific colour. Result of strength and colour direction depend on dyeing condition and kind of fixator in fixation process. Purpose of the research to decide a right of dyeing condition and kind of fixator which were desired in order to produce colour variation, colour strength value, and a good colour fastness. The dyeing was conducted in hot condition (60$70^{\circ} \mathrm{C}$ ) in room temperature $\left(27-30^{\circ} \mathrm{C}\right)$ with fixator $\mathrm{Al}_{2}\left(\mathrm{SO}_{4}\right)_{3}, \mathrm{CaO}$, and $\mathrm{FeSO}_{4}$. Result of the research was found a colour direction that variative enough on silk fabrics from yellow, golden yellow, brownish red, brown, moss green until blackish green. The optimum condition was obtained in hot dyeing $\left(60-70^{\circ} \mathrm{C}\right)$, kind of fixator $\mathrm{CaO}$ that produced intensity and higher darkness colour (K/S value) as high as 19.174 and colour fastness of washing $40^{\circ} \mathrm{C}$, bright light and heat pressure was good until very good (4-5).

\section{Keywords: Gambier, natural dyes, silk fabric, colour strength, colour fastness}

\section{PENDAHULUAN}

Industri tekstil dan produk tekstil (TPT) merupakan salah satu komoditi andalan industri manufaktur dan menjadi motor penggerak pembangunan ekonomi nasional. Prospek pertumbuhan Industri TPT semakin baik dikarenakan permintaan pasar 
di dalam negeri yang meningkat serta tingginya konsumsi dunia. Peningkatan tersebut menuntut produksi tekstil dengan pewarna sintetis secara besar-besaran. Hal ini dengan mudah dapat dilakukan karena zat warna sintetis mudah didapat, praktis dalam penggunaan dengan warna yang tidak terbatas.

Di sisi lain, industri tekstil juga membutuhkan sentuhan dan inovasi baru yang unik, estetis dan mempunyai ciri khas dan bernilai. Kehadiran produk tekstil dengan pewarna alami kembali menimbulkan ketertarikan yang signifikan. Hal ini diperkuat dengan dikeluarkannya regulasi yang mengatur peredaran pewarna tekstil pada tahun 1996 karena pewarna tekstil bersifat karsinogen. Semenjak itu, permintaan pasar terhadap zat warna alami mengalami peningkatan. Berdasarkan data dari UNIDO (Organisasi Pengembangan Industri Perserikatan Bangsa Bangsa) pada tahun 2006 permintaan pewarna alam dunia lebih dari 10,000 ton, dan dapat dipastikan meningkat dari tahun ke tahun.

Keunggulan pemakaian zat warna alami terletak pada kehalusan dan kelembutan warnanya. Produk ini sangat dihargai dan tetap dipertahankan karena mencerminkan keindahan, prestise, struktur budaya yang keberadaannya tidak bisa tergantikan oleh pewarna sintetis. Salah satu langkah yang dapat dilakukan adalah melalui pengaplikasian bahan tradisional ke dalam produk modern.

Penelitian penggunaan pewarna alam untuk tekstil telah banyak dilakukan diantaranya adalah pencelupan wool dan sutera dengan ekstrak Allium cepa (Silva, 2013); Pencelupan sutera dengan Psidium guajuva (Narayanaswamy, 2013); Pencelupan sutera dengan Sticta coronata (Mansour, 2010); Pencelupan kain sutera dengan ekstrak daun sirih (Sunaryati, 2000); Eksplorasi pewarna alam Indigo untuk tekstil (Arimurti dan Sunarya, 2013); Pencelupan kain katun dengan ekstrak Pomegranat (Kulkarni, et al., 2011); Ekstraksi dan karakterisasi pewarna alam Green walnut dan aplikasinya pada serat Poliamida (Mirjalili dan Karimi, 2013); Perbandingan ketahanan luntur dan intensitas warna kain katun yang dicelup dengan pewarna alam (Kumaresan, et al., 2013).
Gambir merupakan ekstrak dari tanaman Uncaria gambier Roxb yang disedimentasikan, dikeringkan dan dicetak. Gambir termasuk komoditi unggulan Propinsi Sumatera Barat yang potensinya selalu terjaga, mudah dalam pendistribusiannya dan mudah didapat dengan harga yang terjangkau. Produksi gambir di Sumatera Barat mencapai 14.220 Ton dengan luas lahan $21.412 \mathrm{Ha}$ dan sentra utamanya adalah Kabupaten 50 Kota dan Pesisir Selatan (Sumatera Barat dalam Angka, 2012). Gambir diekspor ke India, Bangladesh, Taiwan dan Jepang dalam bentuk gambir asalan (produk setengah jadi). Harga jual gambir ditingkat petani sangat rendah dan bervariasi yang ditentukan oleh pedagang pengumpul. Di negara tujuan gambir kemudian diolah kembali menjadi produk turunan dengan harga yang relatif tinggi.

Komponen utama gambir adalah tanin dan katekin. Menurut Thrope dan Whiteley, 1921 dalam Nazir, 2000) kandungan tanin dan katekin gambir berkisar antara $20-55 \%$ dan 7-33\%. Markham (1988), menambahkan bahwa katekin dan tanin dalam bentuk asam katechu tannat termasuk senyawa flavonoid dan antosianin yang pada umumnya merupakan zat warna.

Penelitian pemanfaatan limbah cair hasil pengolahan tanaman gambir telah dilakukan oleh Yusmeiarti, dkk (2005; 2007) yang menghasilkan kain dengan intensitas dan ketahanan luntur warna yang baik, akan tetapi ketersediaan dari limbah cair tersebut belum terjaga secara terus menerus. Sumber zat warna selain limbahnya adalah gambir asalan yang mudah didapat, murah dan ketersediaannya lebih stabil.

Tingkat keberhasilan pencelupan kain dengan zat warna alam dipengaruhi oleh banyak faktor diantaranya adalah kondisi suhu pencelupan, dan jenis fiksator yang digunakan. Untuk itu perlu dilakukan penelitian pewarnaan kain sutera dengan pewarna gambir guna melihat pengaruh kondisi suhu pencelupan dan jenis fiksator yang digunakan dalam menghasilkan kain dengan intensitas warna yang baik, tahan luntur terhadap pencucian, sinar matahari dan penekanan panas serta dengan arah warna yang cukup variatif. 


\section{METODOLOGI PENELITIAN}

Bahan yang digunakan dalam penelitian ini adalah gambir asalan dan kain sutera. Bahan penolong proses terdiri dari $\mathrm{Al}_{2}\left(\mathrm{SO}_{4}\right)_{3}, \mathrm{CaO}, \mathrm{FeSO}_{4}, \mathrm{~K}_{2} \mathrm{CO}_{3}$ (soda abu), dan bahan kimia untuk pengujian diantaranya asam tanat, standar tanin, larutan follindenis, amonium tunstat. Peralatan yang diperlukan adalah neraca analitik, filter, spektrofotometer UV-Vis, grey scale, staining scale standard, dan spektrofotometer "premier color scan SS 6200.

Bahan baku gambir asalan diambil dari Desa Siguntur Kabupaten Pesisir Selatan Propinsi Sumatera Barat. Penelitian dilakukan di Balai Riset dan Standardisasi Industri Padang, sedangkan analisis intensitas warna di Sekolah Tinggi Teknologi Tekstil Bandung dan ketahanan luntur warna di Balai Besar Kerajinan dan Batik Yogyakarta.

Penelitian dilakukan dengan memvariasikan kondisi pencelupan panas (60$70^{\circ} \mathrm{C}$ ) dan dingin (suhu kamar) serta jenis pembangkit warna atau fiksator yaitu $\mathrm{Al}_{2}\left(\mathrm{SO}_{4}\right)_{3}, \mathrm{CaO}$, dan $\mathrm{FeSO}_{4}$. Gambir yang digunakan untuk mewarnai kain sutera adalah gambir asalan dengan konsentrasi $5 \%$, Penggunaan gambir asalan dilakukan karena gambir tersebut telah diperdagangkan di pasaran dalam dan luar negeri dengan harga relatif murah sehingga dapat diperoleh dengan mudah dan harga terjangkau.

Tahapan proses pewarnaan kain menggunakan zat warna alam gambir adalah sebagai berikut:

1. Pembuatan larutan gambir

Gambir asalan dilarutkan dengan air pada perbandingan 1:1, diaduk supaya larut dan homogen, selanjutnya larutan gambir didiamkan semalam (dekantasi) agar terjadi pemisahan komponen gambir berupa katechin dan tanin. Endapan dipisahkan sedangkan filtrat yang banyak mengandung tanin diambil dan digunakan sebagai bahan pewarna.

2. Proses mordanting

Sebelum dimordan kain sutera direndam dalam larutan sabun \pm 5 menit dan tiriskan. Sementara itu $\mathrm{Al}_{2}\left(\mathrm{SO}_{4}\right)_{3}$ ditimbang $5 \mathrm{gr} / \mathrm{L}$, sesuai kebutuhan. Larutkan dengan air panas dengan perbandingan 1:20 atau 1:30. Kain sutera dimasukkan dan dipanaskan pada suhu $60-80^{\circ} \mathrm{C}$ selama \pm 1 jam, matikan api dan diamkan semalam. Kain kemudian dicuci bersih dan dikering-anginkan untuk proses selanjutnya.

3. Proses pencelupan (pewarnaan).

Kain sutera yang sudah dimordan, dalam keadaan kering angin dicelupkan ke dalam larutan gambir selama 5-10 menit. Kain kemudian dikering anginkan, lalu diulangi pencelupannya dan dikeringkan. Hal ini dilakukan sampai tiga kali pencelupan.

4. Proses pembangkitan dan penguncian warna (fiksasi)

- Pembuatan larutan fiksator (fixer).

Penggunaan ketiga jenis fiksator untuk proses fiksasi adalah sebagai berikut: $\mathrm{Al}_{2}\left(\mathrm{SO}_{4}\right)_{3} 10 \mathrm{gr} / \mathrm{L}, \mathrm{CaO} 50$ $\mathrm{gr} / \mathrm{L}$, dan $\mathrm{FeSO}_{4} 30 \mathrm{gr} / \mathrm{L}$. Banyaknya fiksator yang diperlukan sesuai plot (1:30) dan banyaknya kain yang akan dicelup. Larutkan dengan air bersih dan aduk-aduk sampai larut dan homogen, kemudian disedimentasikan selama semalam. Lakukan filtrasi dan endapan atau kotoran dibuang.

- Fiksasi

Kain yang sudah dicelup dengan larutan gambir, selanjutnya difiksasi dengan cara mencelup dalam larutan fiksator yang telah dibuat selama \pm 5 menit, keringkan pada tempat yang teduh dan hindari sinar matahari langsung.

5. Pencucian

Setelah kain difiksasi, direndam dalam air panas untuk kemudian dicuci dengan air dingin sampai warna lunturannya hilang. Selanjutnya kain dikeringkan.

Kain yang sudah diwarnai dengan gambir, selanjutnya diuji terhadap:

1. Intensitas dan ketuaan warna

Pengujian intensitas warna dilakukan dengan metoda Spektrofotometer Cahaya Tampak "Premiere Colorscan" SS 6200. Nilai kuantitatif untuk intensitas warna diperoleh dengan cara mengukur nilai persen reflektansi $(\% R)$ pada panjang gelombang yang sama lalu dikonversikan 
ke nilai $\mathrm{K} / \mathrm{S}$ dengan bantuan tabel $\mathrm{K} / \mathrm{S}$ sesuai dengan teori Kubelka-Munk (persamaan 1).

$$
\mathrm{K} / \mathrm{S}=\frac{(1-\mathrm{R})^{2}}{2 \mathrm{R}}=a C
$$

Dimana $\mathrm{K}$ adalah koefisien absorpsi (cahaya yang diserap); $\mathrm{S}$ adalah koefisien cahaya yang disebarkan; $\mathrm{C}$ merupakan nilai hue dan $\mathrm{R}$ adalah nilai persen reflektansi pada panjang gelombang tertentu ( $\lambda$ max), (Kumaresan et al., 2013; Mirjalili and Karimi, 2013; Sunaryati, 2000).

\section{Ketahanan luntur warna}

Nilai ketahanan luntur warna meliputi nilai perubahan warna dengan cara membandingkan perbedaan warna dengan standar grey scale, dan nilai penodaan warna dengan cara membandingkan perbedaan warna dengan standar staining scale. Penilaiannya adalah sebagai berikut: nilai 5 (baik sekali, tidak ada perubahan warna kain atau penodaan warna terhadap bahan lain), nilai 4 (baik, sedikit terjadi perubahan atau penodaan warna), nilai 3 (cukup, terjadi perubahan atau penodaan warna), nilai 2 (sedang, terjadi perubahan atau penodaan warna yang menyolok) dan nilai 1 (kurang, terjadi perubahan dan penodaan warna yang sangat menyolok).

Uji ketahanan luntur warna kain meliputi;

- Ketahanan terhadap pencucian $40^{\circ} \mathrm{C}$ (perubahan warna dan penodaan warna terhadap asetat, kapas, poliamida, poliester, akrilat, dan wool) sesuai SNI 0276-2009, SNI ISO 105C06-2010;A02, 2010;A03,2010.

- Ketahanan terhadap sinar terang hari sesuai SNI ISO 105-B01-2010; A02, 2010.

- ketahanan terhadap penekanan panas (perubahan warna dan penodaan warna terhadap kapas kering, lembab dan basah) sesuai SNI ISO 105$\mathrm{X} 11,2010$.

\section{HASIL DAN PEMBAHASAN}

\section{Pengamatan Intensitas dan Ketuaan Warna serta Nilai Beda Warna}

Pengamatan intensitas dan ketuaan warna kain dapat dilihat dari nilai K/S.
Semakin tinggi nilai K/S maka warna yang terlihat semakin kuat dan tua. Intensitas warna kain sutera dengan pewarna gambir dapat dilihat pada Tabel 1.

Zat warna alam umumnya memberikan warna pada area panjang gelombang maksimum rendah pada spektrum cahaya tampak. Dari Tabel 1 terlihat bahwa pada fiksator $\mathrm{Al}_{2}\left(\mathrm{SO}_{4}\right)_{3}$ dan $\mathrm{FeSO}_{4}$ dengan kondisi pencelupan yang berbeda (panas dan dingin) menghasilkan intensitas warna yang berbeda. Sedangkan pada fiksator $\mathrm{CaO}$, kondisi pencelupan tidak berpengaruh nyata terhadap tingkat ketuaan warna kain yang dihasilkan.

Tabel 1. Nilai kuantitatif K/S pewarnaan kain sutera dengan pewarna gambir.

\begin{tabular}{|c|c|c|c|}
\hline \multirow{2}{*}{$\begin{array}{c}\text { Kondisi } \\
\text { Pencelupan }\end{array}$} & \multicolumn{3}{|c|}{ Nilai K/S } \\
\cline { 2 - 4 } & $\mathrm{Al}_{2}\left(\mathrm{SO}_{4}\right)_{3}$ & $\mathrm{CaO}$ & $\mathrm{FeSO}_{4}$ \\
\hline $\begin{array}{c}\text { Panas } \\
\left(60-70^{\circ} \mathrm{C}\right)\end{array}$ & 11,583 & 19,174 & 11,551 \\
\hline $\begin{array}{c}\text { Dingin } \\
\text { (suhu kamar) }\end{array}$ & 2,47 & 18,64 & 5,96 \\
\hline
\end{tabular}

Tingkat ketuaan warna ditandai dengan tingginya nilai K/S. Kondisi pencelupan panas menghasilkan intensitas dan ketuaan warna yang lebih tinggi dibandingkan dengan pencelupan dingin. Menurut Djufri (1976), peningkatan suhu pencelupan pada proses pewarnaan akan mempercepat terjadinya ikatan antara molekul zat warna dengan molekul serat. Perbedaan yang signifikan pada perlakuan kondisi pencelupan panas dan dingin terlihat pada penggunaan fiksator $\mathrm{Al}_{2}\left(\mathrm{SO}_{4}\right)_{3}$ dan $\mathrm{FeSO}_{4}$, tetapi tidak berbeda nyata pada pemakaian fiksator $\mathrm{CaO}$.

Dari Tabel 1 juga terlihat bahwa penggunaan fiksator $\mathrm{CaO}$ mempunyai intensitas dan ketuaan warna yang lebih tinggi dibandingkan dengan fiksator $\mathrm{Al}_{2}\left(\mathrm{SO}_{4}\right)_{3}$ dan $\mathrm{FeSO}_{4}$ baik pada kondisi panas maupun dingin. Hal ini kemungkinan disebabkan oleh zat wama yang telah terserap ke dalam serat kain sutera mengadakan ikatan komplek yang lebih banyak dengan ion $\mathrm{Ca}^{+2}$ membentuk molekul yang lebih besar di dalam pori serat, dan pada waktu penyabunan zat wama tersebut lebih sulit untuk keluar lagi dari serat sehingga wama yang timbul menjadi lebih tua. 
Analisa lebih lanjut untuk melihat nilai beda warna dan koordinat warna yang dihasilkan dengan cara membandingkannya terhadap target. Koordinat warna pada sistim CIE L*a*b*, sistim polar $L^{*} C^{*} h$, dapat dilihat pada Tabel 2. Nilai pada sistim CIE menyatakan hue (corak warna), value (kecerahan) yaitu besaran yang menyatakan tua mudanya warna, dan chroma (kejenuhan) yang menyatakan derajat kemurnian suatu warna.

Pewarnaan kain sutera dengan fiksator yang berbeda akan menghasilkan arah warna yang berbeda pula. Kain sutera yang difiksasi dengan larutan $\mathrm{Al}_{2}\left(\mathrm{SO}_{4}\right)_{3}$ menghasilkan warna ke arah kuning, $\mathrm{CaO}$ ke arah merah kecoklatan dan $\mathrm{FeSO}_{4}$ ke arah hijau sampai hijau kehitaman. Arah warna yang berbeda disebabkan oleh penyerapan warna oleh logam yang digunakan sebagai mordan pada proses fiksasi terhadap zat warna tanin dari gambir. Penggunanan fiksator $\mathrm{Al}_{2}\left(\mathrm{SO}_{4}\right)_{3}$ akan menghasilkan warna kain yang dicelup dengan tanin gambir ke arah kuning keemasan, $\mathrm{CaO}$ ke arah merah kecoklatan sedangkan $\mathrm{FeSO}_{4}$ ke arah hijau lumut sampai hijau kehitaman (Yusmeiarti, 2007; Sofyan, 2012; 2013 dan Failisnur, 2013). Menurut Etherington (2002), tanin terkondensasi dalam larutan garam $\mathrm{Fe}^{3+}$ akan menghasilkan warna hijau kehitaman.

Tabel 2. Nilai $L^{*} a^{*} b^{*}, L^{*} C^{*} h$, dan beda warna $\left(\Delta E^{*} a b\right)$ kain sutera pada proses pencelupan panas dan dingin dengan fiksator $\mathrm{Al}_{2}\left(\mathrm{SO}_{4}\right)_{3}, \mathrm{CaO}$ dan $\mathrm{FeSO}_{4}$

\begin{tabular}{|c|c|c|c|c|c|c|}
\hline \multirow{2}{*}{$\begin{array}{c}\text { Nilai Beda } \\
\text { Warna }\end{array}$} & \multicolumn{3}{|c|}{ Pencelupan panas } & \multicolumn{3}{c|}{ Pencelupan panas } \\
\cline { 2 - 7 } & $\mathrm{Al}_{2}\left(\mathrm{SO}_{4}\right)_{3}$ & $\mathrm{CaO}$ & $\mathrm{FeSO}_{4}$ & $\mathrm{Al}_{2}\left(\mathrm{SO}_{4}\right)_{3}$ & $\mathrm{CaO}$ & $\mathrm{FeSO}_{4}$ \\
\hline $\mathrm{L}^{*}$ & 55.69 & 27.57 & 34.53 & 68.40 & 35.99 & 41.55 \\
$\mathrm{a}^{*}$ & 14.17 & 19.85 & 2.24 & 8.13 & 19.36 & 3,21 \\
$\mathrm{~b}^{*}$ & 35.38 & 15.32 & 9,24 & 30.08 & 26.80 & 11.61 \\
$\mathrm{C}^{*}$ & 38.11 & 25.08 & 9.51 & 31.16 & 33.06 & 12.06 \\
$\mathrm{~h}$ & 68.18 & 37.66 & 76.36 & 74.85 & 54.14 & 74.29 \\
\hline
\end{tabular}

Posisi warna perlakuan pencelupan kain sutera dalam kondisi panas dengan menggunakan fiksator kapur pada ruang warna CIE dapat dilihat pada Gambar 1.

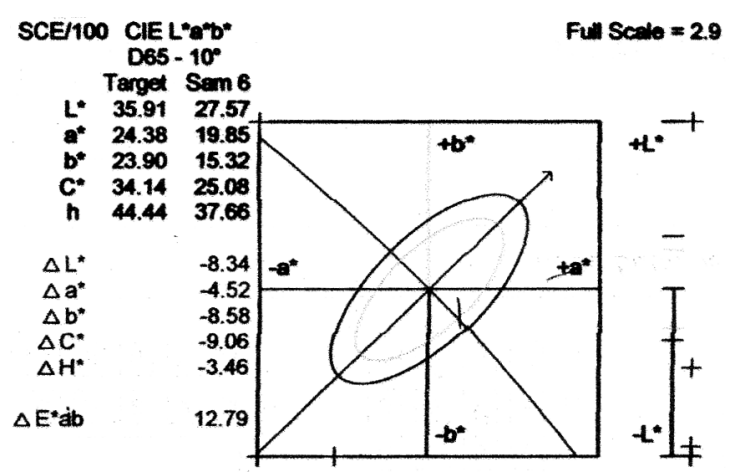

Gambar 1. Nilai $L^{*} a^{*} b^{*}, L^{*} C^{*} h$, dan beda warna $\left(\Delta \mathrm{E}^{*} \mathrm{ab}\right)$ serta posisinya pada ruang warna CIE untuk pencelupan panas dengan fiksator kapur.

Dari Gambar 1 terlihat bahwa fiksator kapur menunjukkan arah warna kemerahan. Warna tersebut terjadi karena adanya reaksi ionik antara tanin (asam tannat atau asam galotannat) dengan ion $\mathrm{Ca}^{2+}$ pada kapur.

Nilai $L^{*}$ direpresentasikan menjadi lebih terang atau lebih gelap (lightness-darkness) pada range 0-100 (putih ke hitam); nilai $a^{*}$ direpresentasikan kemerah-merahan (redness) jika positif dan kehijauan (greennes) jika negatif. Nillai $b^{*}$ adalah kekuningan (yellowness) jika positif dan kebiruan (blueness) jika negatif (Hosseini, 2013).

Antara tanin (asam tannat atau asam galotannat) pada tumbuhan dengan logam $\mathrm{Fe}^{2+}$ pada fiksator tunjung yang menghasilkan garam kompleks (ferro tanat). Garam kompleks tersebut terbentuk karena adanya ikatan kovalen koordinasi antara ion logam dengan ion non logam (Taufik dkk, 2010). Ausokrom dalam tanin akan dapat berikatan lebih baik dengan molekul-molekul serat kain apabila didukung dengan adanya garam-garam kompleks. Ausokrom tersebut merupakan gugus zat warna yang bersifat mengikat warna dengan serat kain serta 
dapat berikatan dengan jenis garam (Gitopadmojo, 1978 dalam Ruwana, 2008).

\section{Ketahanan Luntur Warna}

Hasil analisa ketahanan luntur warna kain terhadap pencucian $40^{\circ} \mathrm{C}$, sinar terang hari dan penekanan panas dapat dilihat pada Tabel 3. Dari Tabel 3 terlihat bahwa ketahanan luntur warna terhadap penodaan pada proses pencucian $40^{\circ} \mathrm{C}$, dan penekanan panas (perubahan dan penodaan warna pada kapas kering dan basah) pada umumnya bernilai baik sampai sangat baik (4-5) kecuali terhadap sinar terang hari dan perubahan warna pada pencucian $40^{\circ} \mathrm{C}$ bernilai cukup sampai baik (3-4). Hal ini berarti tidak ada degradasi pigmen warna karena proses pencelupan sehingga warnanya tetap dan tidak berubah atau tidak luntur.

Tabel3. Hasil pengujian ketahanan luntur warna kain sutera dengan pewarna gambir pada pencelupan panas dan dingin.

\begin{tabular}{|l|l|l|l|l|l|l|}
\hline \multirow{2}{*}{ Hasil Uji } & \multicolumn{3}{|c|}{ Pencelupan panas } & \multicolumn{3}{c|}{ Pencelupan dingin } \\
\cline { 2 - 7 } & $\mathrm{Al}_{2}\left(\mathrm{SO}_{4}\right)_{3}$ & \multicolumn{1}{|c|}{$\mathrm{CaO}$} & $\mathrm{FeSO} 4$ & $\mathrm{Al}(\mathrm{SO} 4) 3$ & $\mathrm{CaO}$ & $\mathrm{FeSO} 4$ \\
\hline Pencucian $40^{\circ} \mathrm{C}$. & & & & & & \\
- Perubahan warna & 3 & 4 & 4 & 3 & $3-4$ & 3 \\
- Penodaan warna & & & & & & \\
Asetat & $4-5$ & $4-5$ & $4-5$ & $4-5$ & 4 & 4 \\
Kapas & 3 & 4 & 4 & $4-5$ & 4 & 4 \\
Poliamida & 3 & $4-5$ & 4 & $4-5$ & $4-5$ & $4-5$ \\
Poliester & $4-5$ & $4-5$ & $4-5$ & $4-5$ & $4-5$ & $4-5$ \\
Akrilat & $4-5$ & $4-5$ & $4-5$ & $4-5$ & $4-5$ & $4-5$ \\
Wool & $4-5$ & $4-5$ & $4-5$ & $4-5$ & $4-5$ & $4-5$ \\
\hline Sinar terang hari & 3 & $4-5$ & $3-4$ & 3 & $3-4$ & 4 \\
\hline Penekanan panas & & $4-5$ & & & & \\
- Perubahan warna & $4-5$ & $4-5$ & $4-5$ & $4-5$ & $4-5$ & $4-5$ \\
- Penodaan warna & & $4-5$ & $4-5$ & $4-5$ & $4-5$ & $4-5$ \\
Kapas kering & $4-5$ & $4-5$ & $4-5$ & $4-5$ & $4-5$ \\
Kapas basah & $4-5$ & $4-5$ & $4-5$ & $4-5$ & & \\
\hline
\end{tabular}

Ketahanan luntur warna dapat diperbaiki melalui proses fiksasi (iring), dimana setelah zat warna terdifusi ke dalam larutan, kemudian terserap (absorbsi) menempel ke permukaan serat, lalu terserap dan terdifusi ke pusat serat tekstil. Supaya zat warna terkunci di dalam serat, maka diperlukan proses fiksasi yang menggunakan logam sebagai fiksator. Fiksator dapat meningkatkan penyerapan zat warna ke dalam serat (Suheryanto, 2010). Proses fiksasi juga dapat meningkatkan sifat ketahanan luntur warna serat kain terhadap pencucian (Narayanaswamy, 2013), dan cahaya (Michel et al., 2002; Mansour, 2011).

Adanya ketahanan luntur yang kuat pada kain sutera terhadap penodaan warna pada pencucian dan penekanan panas berkaitan dengan terjadinya ikatan tanin gambir yang mampu masuk ke dalam serat kain sutera secara maksimum dan berikatan kuat dengan serat kain (Sulasminingsih, 2006). Sebaliknya untuk ketahanan luntur warna terhadap perubahan pada pencucian dan sinar, menurut Asri (2005 dalam Atikasari, 2005) zat warna kurang mampu masuk ke dalam serat secara maksimum dikarenakan putusnya ikatan antara serat kain dengan ausokrom sehingga daya serap serat kain hilang dan menyebabkan sisa zat warna hanya melekat pada permukaan serat kain saja.

Pengaruh kondisi pencelupan terhadap ketahanan luntur warna kain terlihat bahwa pencelupan pada suhu lebih tinggi menghasilkan warna yang lebih tahan terhadap perubahan warna pada pencucian $40^{\circ} \mathrm{C}$ dan perubahan warna terhadap penekanan panas. Jenis serat yang berbeda yaitu serat protein dan selulosa memberikan 
hasil yang tidak berbeda nyata terhadap ketahanan luntur warnanya, baik terhadap pencucian $40^{\circ} \mathrm{C}$, sinar terang hari maupun penekanan panas.

\section{KESIMPULAN}

Pewarna alam gambir pada tekstil menghasilkan arah warna yang cukup variatif mulai dari kuning, kuning keemasan, merah kecoklatan, coklat, hijau lumut sampai hijau kehitaman.

Perlakuan optimal dilihat dari intensitas dan ketahanan luntur warna diperoleh pada penggunaan fiksator $\mathrm{CaO}$ pada kain sutera dengan kondisi pencelupan panas yang memberikan intensitas dan ketuaan warna tertinggi (nilai K/S) sebesar 19,174 dengan ketahanan luntur warna terhadap pencucian $40^{\circ} \mathrm{C}$, sinar terang hari dan penekanan panas bernilai baik sampai sangat baik (4-5).

\section{DAFTAR PUSTAKA}

Arimurti, F.A., dan Sunarya, Y.Y. 2013. Eksplorasi pewarna alam Indigo dipadukan dengan sistim tekstil modular pada produk fesyen. 2013. Jurnal Fakultas Seni rupa dan Desain (FSRD) ITB. Bandung

Atikasari, A. 2005. Kualitas tahan luntur warna batik cap di griya batik Larissa Pekalongan (Skripsi) Universitas Negeri Semarang. Semarang

Badan Pusat Statistik. 2011. Sumatera Barat Dalam Angka. Badan Perencanaan dan Pembangunan Daerah Sumbar. Padang

Badan Standardisasi Nasional. 2010. SNI ISO 105-C 06: 2010. Uji ketahanan luntur warna terhadap pencucian $40^{\circ} \mathrm{C}$ (perubahan dan penodaan warna). BSN. Jakarta.

Badan Standardisasi Nasional. 2010. SNI ISO 105-801: 2010; Uji ketahanan luntur warna terhadap sinar terang hari. BSN. Jakarta.

Badan Standardisasi Nasional. 2010. SNI ISO 105-XII: 2010. Uji ketahanan luntur warna terhadap penekanan panas (nilai perubahan dan penodaan warna). BSN. Jakarta.

Djufri, R., et al, (1976), "Teknologi pengelantangan pencelupan dan pencapan", Institut Teknologi Tekstil, Bandung

Etherington, R. 2002. A Dictionary of descriptive terminology: Vegetable Tannin. http://palimpsest.standard. edu./don/dt.3686.html. Diakses tanggal 4 Januari 2010.

Failisnur dan Yeni, G. 2013. Stabilisasi limbah cair hasil pengolahan gambir dan aplikasinya sebagai pewarna pada kain sutera. Jurnal Biopropal Industri, Volume 4 No. 1 Juni 2013.

Gitopadmojo, 1978. Pengantar kimia zat warna. Institut Teknologi Bandung

Hosseini, M., Montazer, M., Damerchely, R. 2013. Enhancing dye-ability and antibacterial features of silk through pre-treatment with chitosan. Journal of Engineered Fibers and Fabrics Volume 8, Issue 3-2013 http://Www. jeffjournal.org

Kulkarni, S.S., Gokhale A.V., Bodake U.M., Pathade G.R. 2011. Cotton dyeing with natural dye extracted from Pomegranate (Punica granatum) Peel. Universal Journal of Environmental Research and Technology Volume1, Issue 2: 135-139.

Kumaresan, M., et al. 2013. Comparison of fastness properties and colour strength of dyed cotton fabrics with eco-friendly natural dyes. The Experiment, International Journal of Science and Technology Ed. Mar, 2013 Vol. .8(3), 483-489

Mansour, H.F., Heffernan, S. 2011. Environmental aspects on dyeing silk fabric with Sticta coronata lichen using ultrasonic energy and mild mordants. Original paper. Clean Techn Environ Policy (2011) 13:207-213, DOI $10.1007 / \mathrm{s} 10098-010-0296-2$ 
Markham, KR. 1988. Cara mengidentifikasi flavonoid. ITB Bandung

Michel, M.N, Tera FM, Ibrahim SF. 2002. Effect of chemical modification of cotton fabrics on dyeing properties. Journal Applied Polymer Science, 85:1897-1903

Mirjalili, M., and Karimi, L. 2013. Extraction and characterization of natural dye from Green Walnut shells and its use in dyeing Polyamide: Focus on Antibacterial Properties. Journal of Chemistry Volume 2013 (2013), Article ID 375352, 9 pages http://dx.doi.org/ $10.1155 / 2013 / 375352$

Narayanaswamy, V.,Gowda, K.N.N,, Sudhakar, R. 2013. Dyeing and color fastness of natural dye from Psidium guajuva on Silk. Journal of Natural Fibers. 10:3, 257-270, DOI: $10.1080 / 15440478.2013 .797948$

Nazir, N. 2000. Gambir, budidaya, pengolahan dan prospek diversifikasinya. Yayasan Hutanku. Padang

Ruwana, I. 2008. Pengaruh zat fiksasi terhadap ketahanan luntur warna pada proses pencelupan kain kapas dengan menggunakan zat warna dari limbah kayu Jati (Tectona grandis). (Skripsi) Universitas Negeri Semarang.

Silva, A.B., Silva, M.G., Arroyo, P.A., Barros, M.A.S.D. 2013. Dyeing mechanism of wool and silk with extract of Allium cepa. Chemical engineering transactions Vol. 32. AIDIC. The Italian Association of Chemical Engineering.

Sofyan, Failisnur, Salmariza, Marlusi, Muhardi. 2012. Penelitian peningkatan teknologi proses pencelupan kain sutera dengan memanfaatkan limbah cair gambir. Laporan penelitian Baristand Industri Padang.

Sofyan, Failisnur, Marlusi dan Sulastri. 2013. Pengembangan gambir sebagai pewarna alami pada produk tekstil. Laporan penelitian Baristand Industri Padang.

Suheryanto, D. 2010. Optimalisasi celupan ekstrak daun mangga pada kain batik katun dengan iring kapur. Prosiding Seminar Nasional Rekayasa Kimia Dan Proses. Jurusan Teknik Kimia Fakultas Teknik Universitas Diponegoro Semarang

Sulasminingsih. 2006. Studi komparasi kualitas kain kapas pada pencelupan ekstrak kulit kayu pohon Mahoni dengan mordan tawas dan garam diazo. (skripsi). Universitas Negeri Semarang.

Sunaryati, S., Hartini, S., dan Ernaningsih. 2000. Pengaruh tatacara pencelupan zat warna alam daun sirih pada hasil pencelupan kain sutera. Prosiding Pertemuan dan Presentasi IImiah Penelitian Dasar IImu Pengetahuan dan Teknologi Nuklir P3TM-BATAN Yogyakarta. 25-26 Juli 2000.

Taufik, E., Yulianti, A. Barizi, E.K Hayati. 2010. Isolasi dan Identifikasi senyawa aktif ekstrak air daun Paitan (Thitonia diversifolia) sebagai bahan insektisida botani untuk pengendalian hama tungau Eriophyidae. Universitas Maulana Malik Ibrahim . Malang

Thrope JF and Whiteley MA 1921. Thrope's dictionary of applied chemistry. Fourth Edition. Vol.II. Longmans, Green and Co. London. 434-438

Yusmeiarti, Failisnur, Syarief, R., Marjali, dan Yurnita. 2005. Pemanfaatan limbah cair pengolahan gambir untuk pewarna tekstil. Laporan hasil penelitian Balai Riset dan Standardisasi Industri Padang

Yusmeiarti, Failisnur, Hermiyanti, W., Marjali, Syafruddin, D., dan Yurnita. 2007. Penelitian stabilisasi dalam penyimpanan limbah pengolahan gambir sebagai pewarna tekstil. Laporan hasil penelitian Balai Riset dan Standardisasi Industri Padang 